\title{
Synthesis, Spectroscopic Interpretations, and Antioxidant Efficiency of Two Vital Selenium Complexes
}

\author{
F.A.I. AL-KHODIR*
}

Department of Chemistry, College of Science, Princess Nora Bint Abdul Rahman University, Riyadh, Saudi Arabia

(Received September 18, 2016; revised version May 6, 2017; in final form June 23, 2017)

\begin{abstract}
This paper aimed to synthesis, spectroscopic characterizations, and antioxidant assessment of two new selenium complexes with nicotinamide (Nic) and riboflavin (RF) as drug chelates. The speculated structures of the synthetic selenium complexes have been discussed by using different tools of spectroscopic analyses like infrared, the Raman, electronic, ${ }^{1} \mathrm{H}-\mathrm{NMR}$, and mass. Accordingly, the Fourier transform infrared and ${ }^{1} \mathrm{H}-\mathrm{NMR}$ spectra, the mode of complexation is supported, as four molecules of nicotinamide drug act as a monodentate chelate through the Natom of the pyridine ring with $\left[\mathrm{Se}(\mathrm{Nic})_{4}\right] \cdot \mathrm{H}_{2} \mathrm{O}$ formula. The two riboflavin drug molecules coordinated to selenium metal as a bidentate chelate through azomethine nitrogen of pyrazine ring and $\mathrm{O}$-atom of $\mathrm{C}=\mathrm{O}$ pyrimidine- 2,4 dione group with general formula $\left[\mathrm{Se}(\mathrm{RF})_{2}\right]$. Both of Nic and RF chelates act as neutral charge ligands. The conductivity measurements indicated that the selenium complexes are non-electrolytes behaviors. Thermal analyses (thermal gravimetric-differential thermal analysis) of the studied complexes show that the decomposition process takes place in one broadening step with a wide temperature range. The surface morphology of the mentioned complexes was studied by scanning electron microscope and the particle size is calculated using X-ray powder diffraction. Thermodynamic kinetic parameters are calculated by using the Coats and Redfern equation. Screening of antioxidant activities of selenium complexes in vitro are assessed. The antioxidant activity is studied by three methods (DPPH assay, $\beta$-carotene/linoleic acid bleaching assay, and ferric reducing power assay), the studied complexes have a significant antioxidant activity compared to synthetic antioxidants like trolox and BHT.
\end{abstract}

DOI: 10.12693/APhysPolA.132.1265

PACS/topics: nicotinamide, riboflavin, selenium, syntheses, characterization, antioxidant

\section{Introduction}

Selenium element and organoselenium play an essential role in the biological systems [1-7]. Generally, metal ions were required for many critical functions in humans [810]. Metal complexes have played key role in the development of modern chemotherapy [11-14], however, the study of metal-drug complexes is still in its early stages, thus representing a great challenge in current synthetic chemistry and coordination chemistry.

Nicotinamide namely vitamin $\mathrm{B}_{3}$ (Fig. 1A) has been demonstrated as anti-inflammatory actions and anticancer agent $[15,16]$. Some transition metal complexes of nicotinamide have been discussed both structurally and spectroscopically [17-24]. Riboflavin (Fig. 1B) is a member of vitamins (B complex) that is an important antioxidant agent. There is little attention in the literature about the complexation of RF [25-27]. For the first time Malele et al. [26] synthesized and characterized $\mathrm{RF}-$ $\mathrm{Mo}(\mathrm{V})$ complex in powder form using $\left[\mathrm{Mo}_{2} \mathrm{O}_{4}\left(\mathrm{H}_{2} \mathrm{O}\right)_{6}\right]^{2+}$ complex as a precursor for the synthesis.

Vitamins have a number of essential functions in the body, main role is as an antioxidant. It protects body cells from toxic compounds, heavy metals, such as lead and cadmium, and also from the side effects of drugs, radiation and free radical damage. This research aims

\footnotetext{
*e-mail: fatimaalkhodir@yahoo.com
}

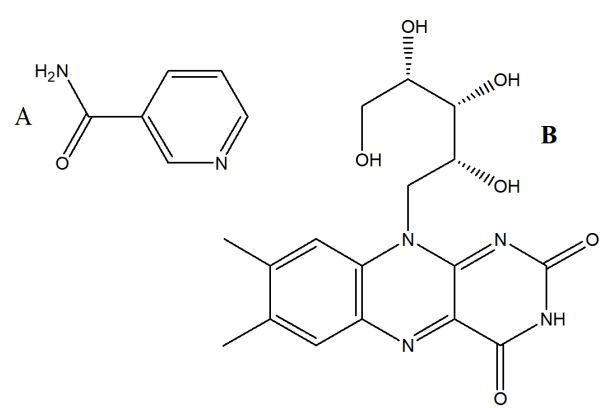

Fig. 1. Structures of nicotinamide (A) and riboflavin (B) drugs.

to prepare new selenium compounds with in vitro screening of antioxidant properties by combining the selenium element in a metallic state with both nicotinamide and riboflavin vitamins to form an antioxidant pharmacological model. There are little spectroscopic characterizations and thermal stability about the chemical interaction between vitamin drugs and selenium metal.

\section{Experimental \\ 2.1. Reagents}

All chemicals used throughout this study were Analar or extra pure grade and received from Aldrich chemical company. The selenium metal, nicotinamide, and riboflavin used in this paper were of analytical grade and used without further purification. The solvents were used without distillation. 2,2-diphenyl-1- 
picrylhydrazyl (DPPH), methanol, $n$-hexane, 2-deoxy-2ribose, $\beta$-carotene and linoleic acid, were procured from Sigma (Sigma-Aldrich GmbH, Sternheim, Germany). Tween 40 and dimethyl sulphoxide (DMSO) were from Merck (Darmstadt, Germany).

\subsection{Synthesis of Nic and RF selenium complexes}

A mixtures of solid powder of selenium metal $(4 \mathrm{mmol})$ with nicotinamide $(16 \mathrm{mmol})$ or riboflavin $(8 \mathrm{mmol})$ in toluene solvent $(50 \mathrm{~mL})$ were refluxed for $24 \mathrm{~h}$ at $60^{\circ} \mathrm{C}$. The unreacted selenium metal powder was removed by filtration, and the color resultants solutions were reduced to $c a$. $1 / 3$ of its volume and cooled to room temperature. The solid complexes obtained were then collected by filtration, washed with little amount of toluene and dried in vacuo over anhydrous calcium(II) chloride. The purity was checked by thin layer chromatography.

\subsection{Instruments}

The micro-analytical analyses of $\% \mathrm{C}$ and $\% \mathrm{H}$ percentages were calculated using a Perkin Elmer CHN 2400 (USA). The metal content was determined gravimetrically by converting the compounds to its corresponding stable form. The molar conductivity of the two selenium complexes with $10^{-3} \mathrm{~mol} / \mathrm{cm}^{3}$ concentration in DMSO solvent was measured using Jenway 4010 conductivity meter. The UV-vis absorption spectra were recorded in DMSO solvent within 800-200 $\mathrm{nm}$ range using a UV2-Unicam UV/Vis Spectrophotometer fitted with a quartz cell of $1.0 \mathrm{~cm}$ path length. The infrared spectra with $\mathrm{KBr}$ discs were recorded on Bruker FT-IR Spectrophotometer (4000-400 $\mathrm{cm}^{-1}$ ), while Raman laser spectra of samples were measured on the Bruker FTRaman with laser $50 \mathrm{~mW}$. The thermal studies (thermogravimetric/differential thermal gravimetric, TG/DTG$50 \mathrm{H})$ were carried out on a Shimadzu thermogravimetric analyzer under nitrogen till $800^{\circ} \mathrm{C}$. All experiments were performed using a single loose top loading platinum sample pan under nitrogen atmosphere at a flow rate of $30 \mathrm{~mL} / \mathrm{min}$ and $\mathrm{a} 10^{\circ} \mathrm{C} / \mathrm{min}$ heating rate for the temperature range $25-800^{\circ} \mathrm{C} .{ }^{1} \mathrm{H}-\mathrm{NMR}$ spectra were recorded as DMSO solutions on a Bruker $600 \mathrm{MHz}$ spectrometer using TMS as the internal standard. Scanning electron microscopy (SEM) images were obtained using a JEOL Jem-1200 EX II electron microscope at an acceleration voltage of $25 \mathrm{kV}$. X-ray diffraction (XRD) patterns of the sample was recorded on X Pert Philips X-ray diffractometer. All the diffraction patterns were obtained by using $\mathrm{Cu} K_{\alpha 1}$ radiation, with a graphite monochromator at $0.02^{\circ} / \mathrm{min}$ scanning rate.

\subsection{Anti-oxidative assays}

The antioxidant activity of selenium complexes were measured in terms of hydrogen-donating or radicalscavenging ability, using the stable radical DPPH as a reagent [28]. The $\beta$-carotene/linoleic acid bleaching assay was determined by measuring the inhibition of selenium complexes and conjugated diene hydroperoxides arising from linoleic acid oxidation by described method [29]. The reductive potential based on the ferric reducing antioxidant power of the studied complexes and the standards positive controls (BHT and trolox) was determined [30]. Each of the measurements described was carried out in three replicate experiments and the results are recorded as mean \pm standard deviation. The significantly different calculated at level of $p \leq 0.05$.

\subsection{Thermodynamic activation parameters}

The thermodynamic activation parameters of decomposition processes of Nic and RF selenium complexes namely activation energy $\left(E^{*}\right)$, enthalpy $\left(\Delta H^{*}\right)$, entropy $\left(\Delta S^{*}\right)$ and Gibbs free energy change of the decomposition $\left(\Delta G^{*}\right)$ were evaluated graphically by employing the Coats-Redfern relation [31]. The entropy of activation $\left(\Delta S^{*}\right)$, enthalpy of activation $\left(\Delta H^{*}\right)$ and the free energy change of activation $\left(\Delta G^{*}\right)$ were calculated using the following equations:

$$
\begin{aligned}
& \Delta S^{*}=2.303(\log (A h / k T) R, \\
& \Delta H^{*}=E^{*}-R T, \\
& \Delta G^{*}=\Delta H^{*}-T \Delta S^{*} .
\end{aligned}
$$

\section{Results and discussion}

\subsection{Micro-analytical and physical study}

The analytical, physicochemical results and spectroscopic outcome are in a good agreement with the speculated structures of mentioned two selenium complexes. The elemental analyses data of the selenium complexes of nicotinamide and riboflavin reveal that the two complexes have 1:4and 1:2 stoichiometry (metal:ligand), respectively. The resulting selenium complexes are soluble in DMSO and DMF with gently warming but insoluble with alcohols and other organic solvents. The physicochemical results like color, yield, melting point as well as molar conductance values of these complexes are listed in Table I. At room temperature, the conductance data of the selenium complexes which dissolved in DMSO are existing within $12-14 \Omega^{-1} \mathrm{~cm}^{2} \mathrm{~mol}^{-1}$ range, these data confirm that the two prepared selenium complexes are non-electrolytes [32]. The speculated structures of both selenium complexes with Nic and RF are represented in Fig. 2.

TABLE I

Physical data: color, melting point $\left[{ }^{\circ} \mathrm{C}\right]$, $\Lambda_{m}\left[\Omega^{-1} \mathrm{~cm}^{2} \mathrm{~mol}^{-1}\right]$, yield, and elemental analysis \% found $/(\%$ calc. $)$ of Se(IV) folate complex.

\begin{tabular}{c|c|c|c|c||c|c|c}
\hline \hline $\begin{array}{c}\text { Empirical } \\
\text { formula }\end{array}$ & Color & M.P. & $\Lambda_{m}$ & Yield & $\mathrm{C}$ & $\mathrm{H}$ & $\mathrm{Se}$ \\
\hline$\left[\mathrm{Se}(\mathrm{Nic})_{4}\right] . \mathrm{H}_{2} \mathrm{O}$ & light pink & 279 & 12 & 84 & $\begin{array}{c}49.27 \\
(49.23)\end{array}$ & $\begin{array}{c}4.40 \\
(4.48)\end{array}$ & $\begin{array}{c}13.43 \\
(13.49) \\
49.08\end{array}$ \\
$\begin{array}{c}4.72 \\
\left(\mathrm{Se}(\mathrm{RF})_{2}\right]\end{array}$ & yellow & 320 & 14 & 88 & $\begin{array}{c}9.44 \\
(49.10)\end{array}$ \\
$(4.85)$ & $(9.49)$
\end{tabular}




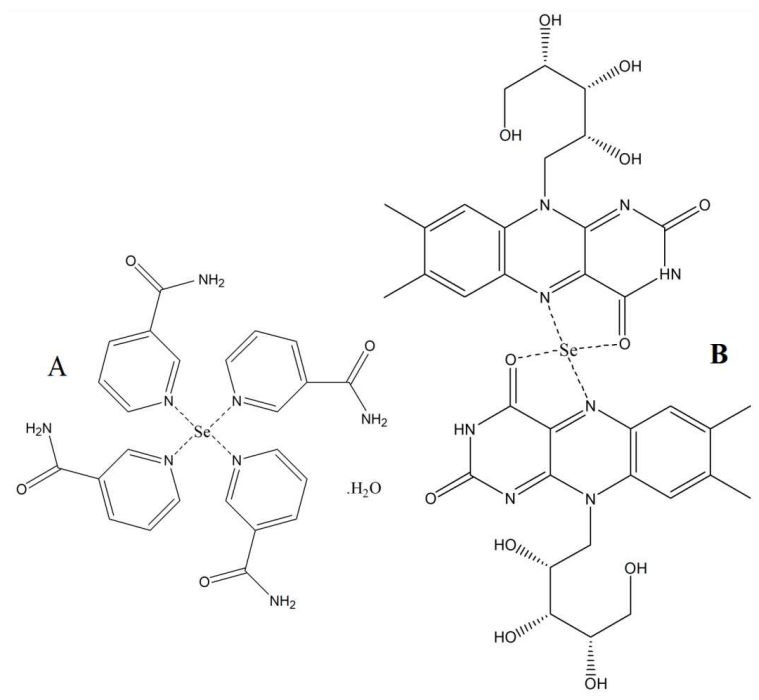

Fig. 2. (A) The speculated formula of selenium nicotinamide complex, (B) the speculated formula of selenium riboflavin complex.

\subsection{Infrared and Raman spectra}

The infrared spectra of the nicotinamide and riboflavin selenium complexes (Fig. 3) are compared with that of the Nic and RF as free ligands to notify the changes that might have taken place during the complexation (Tables II and III).

The FT-IR spectrum of $\left[\mathrm{Se}(\mathrm{Nic})_{4}\right] \cdot \mathrm{H}_{2} \mathrm{O}$ complex is shown in Fig. 3 and its spectral data (Table II) are as-

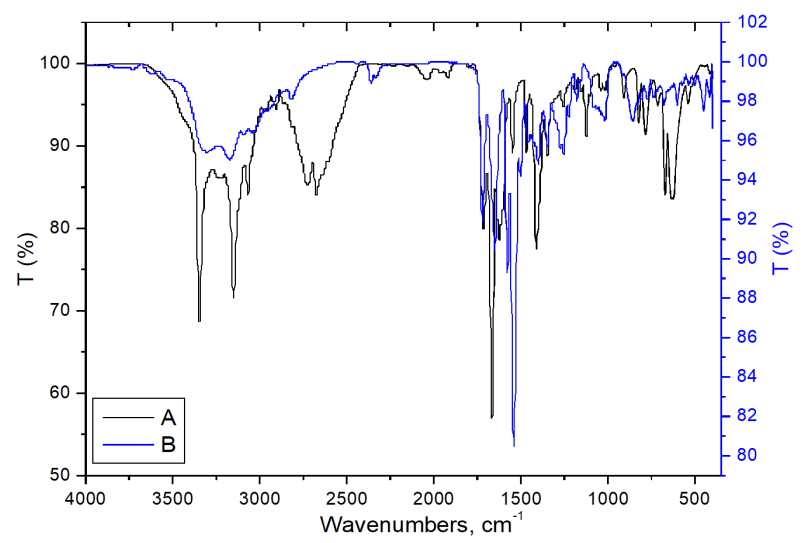

Fig. 3. FT-IR spectrum of (A) $\left[\mathrm{Se}(\mathrm{Nic})_{4}\right] \cdot \mathrm{H}_{2} \mathrm{O}$ and (B) $\left[\mathrm{Se}(\mathrm{RF})_{2}\right]$ complexes.

signed to give an idea about the place of the coordination between the selenium metal and Nic ligand. The infrared spectrum of Nic selenium complex shows bands at $3345 \mathrm{~cm}^{-1}$ which is not existed in the free chelate, that this band is assigned to the $\nu(\mathrm{O}-\mathrm{H})$ stretching vibration motion of uncoordinated water molecule. The stretching vibration motion $\nu(\mathrm{N}-\mathrm{H})$ of $-\mathrm{NH}_{2}$ group is presented at $3150 \mathrm{~cm}^{-1}$ in case of complex form, this supported that it is not participated in the coordination process. The shifted in the wave numbers of the pyridine ring gave
TABLE II

Assignment of IR spectral data of $\mathrm{Nic}$ and $\left[\mathrm{Se}(\mathrm{Nic})_{4}\right] \cdot \mathrm{H}_{2} \mathrm{O}$ complex.

\begin{tabular}{|c|c|c|c|c|c|}
\hline \multirow[b]{2}{*}{ Compound } & \multicolumn{5}{|c|}{ Assignment } \\
\hline & $\nu(\mathrm{OH})$ & $\nu(\mathrm{NH})$ & $\nu(\mathrm{CH})$ & \begin{tabular}{|l|}
$\nu(\mathrm{C}=\mathrm{O})$ \\
$\nu(\mathrm{C}=\mathrm{C})$ \\
$\nu(\mathrm{C}=\mathrm{N})$
\end{tabular} & $\mathrm{Se}-\mathrm{N}$ \\
\hline $\mathrm{Nic}$ & - & 3200 & $\begin{array}{l}3060 \\
2787 \\
2777 \\
2765\end{array}$ & $\begin{array}{ll}1699 & 1681 \\
1621 & 1593 \\
1576 & 1486 \\
1423 & 1404 \\
1396 & 1341 \\
1254 & 1232\end{array}$ & \\
\hline$\left[\mathrm{Se}(\mathrm{Nic})_{4}\right] \cdot \mathrm{H}_{2} \mathrm{O}$ & $\begin{array}{l}3345 \\
3250\end{array}$ & 3221 & $\begin{array}{l}3068 \\
2972 \\
2904 \\
2723\end{array}$ & $\begin{array}{lll}1715 & 1666 \\
1624 & 1549 \\
1467 & 1411 \\
1347 & 1257\end{array}$ & $\begin{array}{l}539 \\
415\end{array}$ \\
\hline
\end{tabular}

TABLE III

Assignment of IR spectral data of $\mathrm{RF}$ and $\left[\mathrm{Se}(\mathrm{RF})_{2}\right]$ complex.

\begin{tabular}{|c|c|c|c|c|}
\hline \multirow[b]{2}{*}{ Compound } & \multicolumn{4}{|c|}{ Assignment } \\
\hline & $\begin{array}{l}\nu(\mathrm{OH}) \\
\nu(\mathrm{NH})\end{array}$ & $\nu(\mathrm{CH})$ & $\begin{array}{l}\nu(\mathrm{C}=\mathrm{O}) \\
\nu(\mathrm{C}=\mathrm{C}) \\
\nu(\mathrm{C}=\mathrm{N})\end{array}$ & $\mathrm{Se}-\mathrm{N}$ \\
\hline $\mathrm{RF}$ & $\begin{array}{l}3372 \\
3362 \\
3180\end{array}$ & $\begin{array}{l}3112 \\
2935\end{array}$ & $\begin{array}{lll}1732 & 1716 & 1649 \\
1622 & 1581 & 1548 \\
1505 & 1459 & 1436 \\
1398 & 1369 & 1346\end{array}$ & \\
\hline$\left[\mathrm{Se}(\mathrm{RF})_{2}\right]$ & $\begin{array}{l}3304 \\
3172\end{array}$ & $\begin{array}{l}3043 \\
2817\end{array}$ & $\begin{array}{ccc}17221649 & 1577 \\
1542 & 15021401 \\
& 1347\end{array}$ & $\begin{array}{ll}601 & 538 \\
451 & 417\end{array}$ \\
\hline
\end{tabular}

an indication about the formation of bond between the nitrogen of pyridine ring and selenium metal [33].

The infrared spectrum of the $\left[\mathrm{Se}(\mathrm{RF})_{2}\right]$ complex (Fig. 3) is compared with its RF free ligand to notify the changes occurring during the complexation (Table III). In case of free RF ligand, the bands at (1732 and $1716 \mathrm{~cm}^{-1}$ ) and $1548 \mathrm{~cm}^{-1}$ are corresponding to the stretching vibrations of $\mathrm{C}=\mathrm{O}$ amide group and $\mathrm{C}=\mathrm{N}$ of conjugated system, respectively. These frequencies are shifted or absent in complexation state, due to the involvement of the $\mathrm{C}=\mathrm{O}$ and $\mathrm{C}=\mathrm{N}$ in coordination process [33]. The free $\mathrm{RF}$ ligand and its selenium complex have an intense peak at $3172 \mathrm{~cm}^{-1}$, which is assigned to stretching frequency of -NH group attached with the heterocyclic ring. This interpretation confirms that the $-\mathrm{NH}$ group is free from the sharing in the complexation. The IR spectrum of the RF selenium complex has a broadening band at $3304 \mathrm{~cm}^{-1}$, which is assigned to the stretching band of $\mathrm{O}-\mathrm{H}$ group.

The Raman spectra of Nic and RF selenium complexes are assigned and illustrated in Fig. 4. The Raman spectra are found to be a complementary with infrared spectroscopic techniques. The two new bands which are exhibited in both infrared and Raman spectra at around 


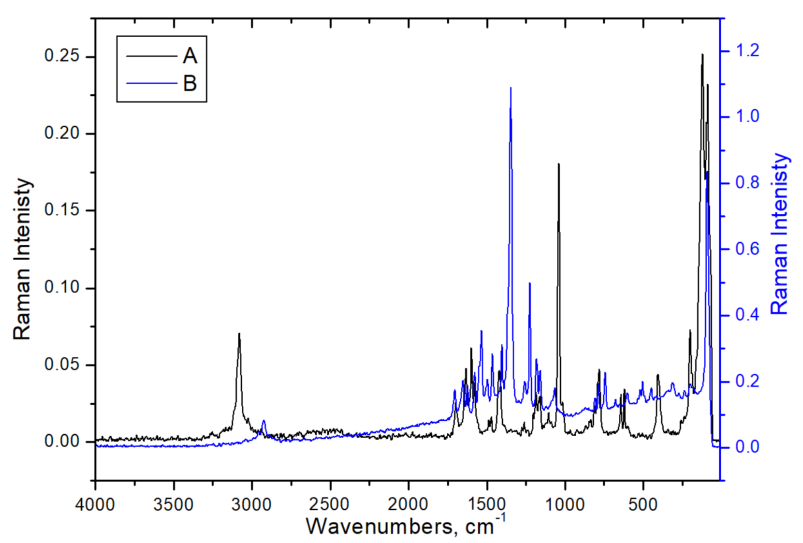

Fig. 4. Raman spectrum of (A) $\left[\mathrm{Se}(\mathrm{Nic})_{4}\right] \cdot \mathrm{H}_{2} \mathrm{O}$ and (B) $\left[\mathrm{Se}(\mathrm{RF})_{2}\right]$ complexes.

600 and $400 \mathrm{~cm}^{-1}$, respectively are assigned to $\nu(\mathrm{M}-\mathrm{O})$ and $\nu(\mathrm{M}-\mathrm{N})$, that refer to binding of selenium ions with oxygen and nitrogen atoms.

\subsection{Electronic spectra}

Figures 5 and 6 refer to the electronic (UV-vis) spectra of the Nic and RF selenium complexes, respectively. The nicotinamide chelate has absorption spectra in the

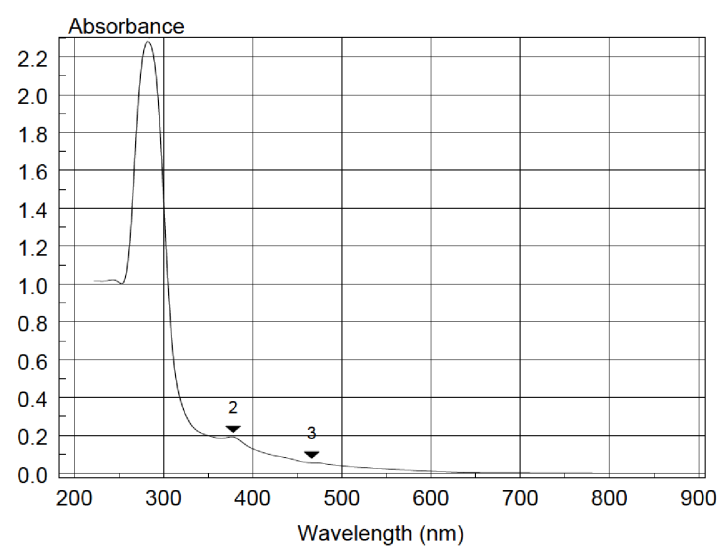

Fig. 5. Electronic spectrum of Se(IV)Nic complex.



Fig. 6. Electronic spectrum of Se(IV)RF complex. ultraviolet region in the region of the $200-400 \mathrm{~nm}$ and in some cases these bands extends over to higher wavelength region due to conjugation. But upon complexation with selenium metal, due to interaction with the metal ion there will be an interesting change in the electronic properties of the system. New bands in the visible region due to charge transfer spectra from metal to ligand (M$\mathrm{L})$ or ligand to metal $(\mathrm{L}-\mathrm{M})$ can be observed and this data can be processed to obtain information regarding the structure of the complexes [34]. Electronic spectrum of $\left[\mathrm{Se}(\mathrm{Nic})_{4}\right] \cdot \mathrm{H}_{2} \mathrm{O}$ complex was recorded in DMSO with $10^{-3} \mathrm{~mol} / \mathrm{cm}^{3}$. UV-visible peaks corresponding to the $\pi \rightarrow \pi^{*}$ transition in the Nic complex was observed at $284 \mathrm{~nm}$ [35]. The peak belonging to $n \rightarrow \pi^{*}$ transition is recorded at wavelength $378 \mathrm{~nm}$ [36]. The first range can be assigned to $\pi \rightarrow \pi^{*}$ transitions in the aromaticity of pyridine ring while the second range is most probably due to the $n \rightarrow \pi^{*}$ transitions of $\mathrm{NH}_{2}$ and carbonyl of amide group beside to nitrogen atom of pyridine ring [37]. The third type of transition in visible region located at $466 \mathrm{~nm}$ can be attributed to the ligand-to-metal charge transfer bands $\mathrm{LM}_{C T}$ from the electronic lone pairs of pyridine nitrogen to the metal ions [38].

The absorption spectrum of RF free chelate exhibits four peaks [39] at 223, 267, 375, and $444 \mathrm{~nm}$, respectively. The first two bands are due to $\pi \rightarrow \pi^{*}$ transitions but the other two bands at 375 and $444 \mathrm{~nm}$ are assigned to $n \rightarrow \pi^{*}$ transitions. After complexation, the spectrum of $\left[\mathrm{Se}(\mathrm{RF})_{2}\right]$ complex has four absorption bands at 276, 384,398 , and $444 \mathrm{~nm}$ with a red shift due to coordination towards selenium metal.

\section{4. ${ }^{1} H-N M R$ spectra}

The ${ }^{1} \mathrm{H}-\mathrm{NMR}$ spectrum of free nicotinamide chelate displays four chemical shifts at $\delta=9.081,8.735,8.249$, and $7.527 \mathrm{ppm}$ due to $4 \mathrm{H}$ of pyridine ring and two other peaks at $\delta=8.22$ and 7.67 ppm which are corresponding to $2 \mathrm{H}$ of $-\mathrm{NH}_{2}$ amido group. The ${ }^{1} \mathrm{H}-\mathrm{NMR}$ spectrum of $\left[\mathrm{Se}(\mathrm{Nic})_{4}\right] \cdot \mathrm{H}_{2} \mathrm{O}$ complex (Fig. 7) has some peaks at $(\delta=8.528,8.702,8.717,8.905,8.914$, and $9.212 \mathrm{ppm})$, $(\delta=7.909,7.921$, and $7.936 \mathrm{ppm}), \delta=5.831 \mathrm{ppm}$ due to $4 \mathrm{H}$ of pyridine ring, $2 \mathrm{H}$ of $-\mathrm{NH}_{2}$ and $2 \mathrm{H}$ of $\mathrm{H}_{2} \mathrm{O}$, respectively. This results indicates that the coordination take place through $-\mathrm{N}$ atom of pyridine ring and far away of both $-\mathrm{N}$ and $-\mathrm{O}$ atoms of amido group. The presence of new chemical shift at $5.831 \mathrm{ppm}$ due to $2 \mathrm{H}$ of water molecule support the located of uncoordinated water molecule outside the coordination sphere.

${ }^{1} \mathrm{H}-\mathrm{NMR}$ spectrum of riboflavin free chelate in DMSO$d_{6}$ refer to distinguishing of peaks for the imide proton that is observed at $11.34 \mathrm{ppm}$, aromatic protons are at $7.92 \mathrm{ppm}$, methyl groups are observed at $3.64 \mathrm{ppm}$ and $2.41 \mathrm{ppm}$, protons of the side chain including the $\mathrm{O}-\mathrm{H}$ protons are observed in the range from $2.50-5.14 \mathrm{ppm}$. In case of ${ }^{1} \mathrm{H}-\mathrm{NMR}$ spectrum of $\left[\mathrm{Se}(\mathrm{RF})_{2}\right]$ complex (Fig. 8), the protons of aromatic rings, methyl groups, $\mathrm{O}-\mathrm{H}$ protons are observed with small chemical shifts and the proton of $-\mathrm{NH}$ imide group is still unshifted which exhibited 


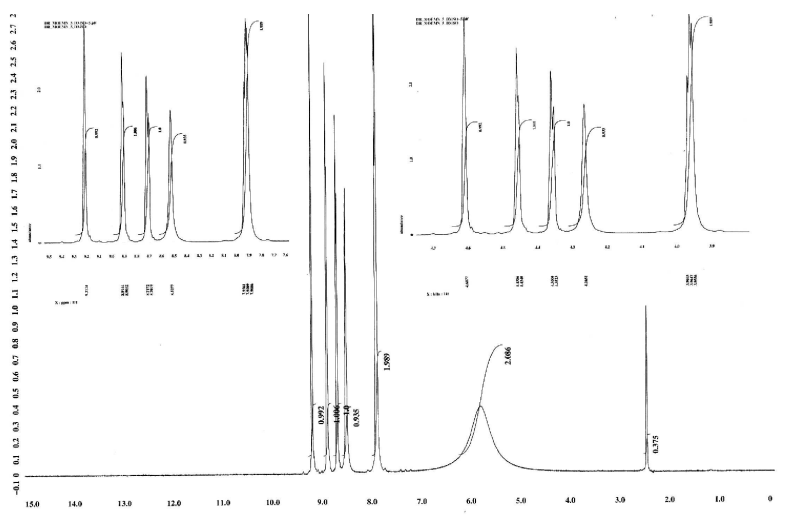

Fig. 7. ${ }^{1} \mathrm{H}-\mathrm{NMR}$ spectrum of $\left[\mathrm{Se}(\mathrm{Nic})_{4}\right] \cdot \mathrm{H}_{2} \mathrm{O}$ complex.

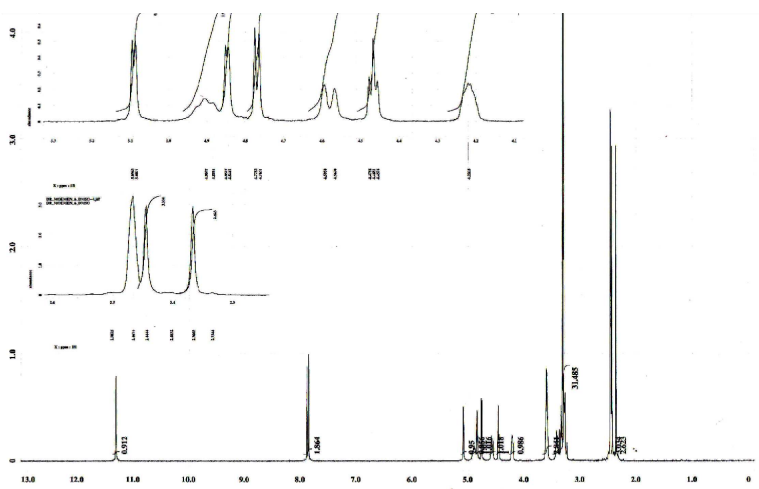

Fig. 8. ${ }^{1} \mathrm{H}-\mathrm{NMR}$ spectrum of $\left[\mathrm{Se}(\mathrm{RF})_{2}\right]$ complex. at $\delta=11.32$, these results confirm that the $\mathrm{RF}$ coordinated to selenium metal through $-\mathrm{N}$ and $-\mathrm{O}$ atom of pyrimidine-2,4-dione moiety and the $-\mathrm{N}$ of $-\mathrm{NH}$ imide group far away of chelation. The large peak at $2.50 \mathrm{ppm}$ belongs to DMSO.

\subsection{Thermal analyses}

The TG curves for the $\left[\mathrm{Se}(\mathrm{Nic})_{4}\right] \cdot \mathrm{H}_{2} \mathrm{O}$ and $\left[\mathrm{Se}(\mathrm{RF})_{2}\right]$ complexes are shown in Fig. 9. Based on the TG curve, the following mass loss sequences can be proposed concerning $\left[\mathrm{Se}(\mathrm{Nic})_{4}\right] \cdot \mathrm{H}_{2} \mathrm{O}$ complex. The first mass loss is associated with the release of one uncoordinated water molecule with calculated $3.07 \%$; found $2.66 \%$ at $\mathrm{DTG}_{\max }=76^{\circ} \mathrm{C}$. The release of uncoordinated water molecule is followed by the release of four Nic molecules with calculated $83.44 \%$; found $83.93 \%$ at $\mathrm{DTG}_{\max }=$ $300{ }^{\circ} \mathrm{C}$. The selenium metal is a final degradation with calculated $13.49 \%$; found $13.41 \%$.

It is clearly obviously that for the TG curve of the $\left[\mathrm{Se}(\mathrm{RF})_{2}\right]$ complex there does not exist any mass loss up to $200^{\circ} \mathrm{C}$, which is interpreted as the thermal stability. At $320^{\circ} \mathrm{C}$, this complex lost two riboflavin (RF) molecules with calculated $84.74 \%$; found $84.10 \%$. The final decomposition product is selenium metal contaminated with four carbon atoms as a solid residual with calculated $15.26 \%$; found $15.90 \%$.

The thermodynamic activation data are summarized in Table IV. The activation energies of decomposition were found to be in the range $125-181 \mathrm{~kJ} \mathrm{~mol}^{-1}$. The high

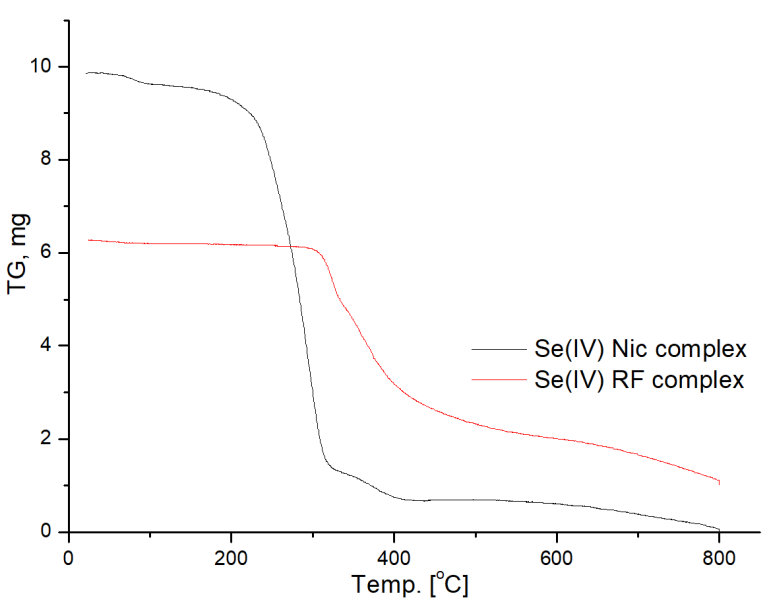

Fig. 9. TGA diagrams of $\mathrm{Se}(\mathrm{IV}) \mathrm{Nic}$ and $\mathrm{Se}(\mathrm{IV}) \mathrm{RF}$ complexes.

values of the activation energies reflect the thermal stability of the complexes [40-44]. The entropy of activation was found to have negative values in all the complexes which indicate that the decomposition reactions proceed with a lower rate than the normal ones.

TABLE IV

Thermodynamic parameters of the A $\left[\mathrm{Se}(\mathrm{Nic})_{4}\right] \cdot \mathrm{H}_{2} \mathrm{O}$ and $\mathrm{B}\left[\mathrm{Se}(\mathrm{RF})_{2}\right]$ complexes.

\begin{tabular}{c|c|c|c|c|c|c}
\hline \hline & \multicolumn{5}{|c|}{ Parameter } & \multirow{2}{*}{$r$} \\
\cline { 2 - 6 } & $\begin{array}{c}E \\
{\left[\mathrm{~kJ} \mathrm{~mol}^{-1}\right]}\end{array}$ & $\begin{array}{c}A \\
{\left[\mathrm{~s}^{-1}\right]}\end{array}$ & $\begin{array}{c}\Delta S \\
{\left[\mathrm{~J} \mathrm{~mol}^{-1} \mathrm{~K}^{-1}\right]}\end{array}$ & $\begin{array}{c}\Delta H \\
{\left[\mathrm{~kJ} \mathrm{~mol}^{-1}\right]}\end{array}$ & $\begin{array}{c}\Delta G \\
{\left[\mathrm{~kJ} \mathrm{~mol}^{-1}\right]}\end{array}$ & \\
\hline $\mathrm{A}$ & 125 & $1.62 \times 10^{10}$ & -54 & 121 & 149 & 0.9904 \\
\hline $\mathrm{B}$ & 181 & $-4.97 \times 10^{13}$ & -12 & 175 & 168 & 0.9957
\end{tabular}

\subsection{X-ray powder diffraction and SEM studies}

The XRD diffraction patterns within the $0^{\circ}<2 \theta<$ $80^{\circ}$ range for the $\left[\mathrm{Se}(\mathrm{Nic})_{4}\right] \cdot \mathrm{H}_{2} \mathrm{O}$ and $\left[\mathrm{Se}(\mathrm{RF})_{2}\right]$ complexes were carried out in order to obtain an idea about the lattice dynamics of these complexes (Figs. 10 and 11). All definite peaks of Se metal, Nic and RF are indexed, which are matched and compared with the standard data. The

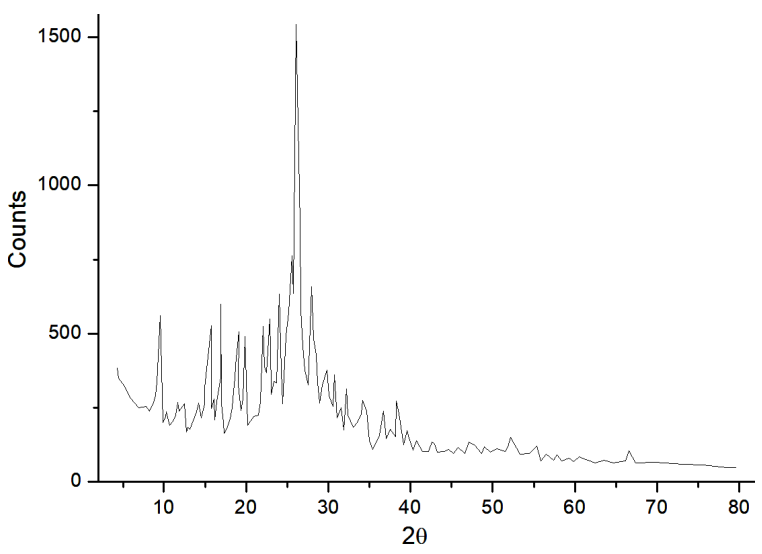

Fig. 10. XRD patterns of $\left[\mathrm{Se}(\mathrm{Nic})_{4}\right] \cdot \mathrm{H}_{2} \mathrm{O}$. 


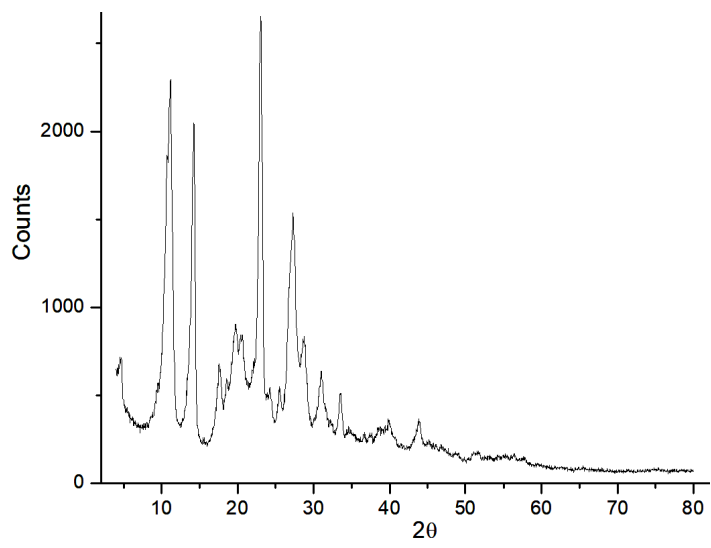

Fig. 11. XRD patterns of $\left[\mathrm{Se}(\mathrm{RF})_{2}\right]$ complex.



Fig. 12. SEM photo of $\left[\mathrm{Se}(\mathrm{Nic})_{4}\right] \cdot \mathrm{H}_{2} \mathrm{O}$ complex.

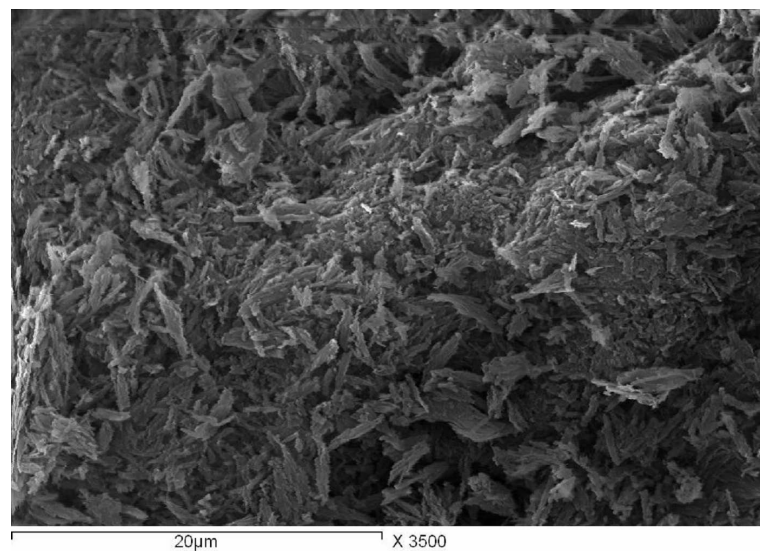

Fig. 13. SEM photo of $\left[\mathrm{Se}(\mathrm{RF})_{2}\right]$ complex.

grain size for nanocompounds were calculated according to the Scherrer formula [45].

Purity and morphology of the nicotinamide and riboflavin selenium complexes obtained were studied using SEM to confirm the fact that each solid represents a definite compound of a definite structure which is not contaminated with starting materials. The obtained SEM micrographs, shown in Figs. 12 and 13, is allowed to verify that these complexes are the ones with the well formed crystalline shapes. Such facts are in agreement with the formation of new complexes and were supported by the XRD data.

\subsection{Antioxidant activity}

The potential antioxidant activity of the tested samples was determined on the basis of three methods, the scavenging activity of the stable free radical DPPH $\left(\mathrm{EC}_{50}\right.$ value); inhibition of the coupled oxidation of linoleic acid and beta-carotene (AA \% value) and ferric reducing antioxidant power $\left(\mathrm{EC}_{1}\right.$ value). Since the reaction followed a concentration-dependent pattern, only values of $\mathrm{EC}_{50}$; $\mathrm{AA} \%$ and $\mathrm{EC}_{1}$ of each sample; $\mathrm{BHT}$ and Trolox are presented in Table V. In general, the lower the $\mathrm{EC}_{50}$ value the higher then free radical scavenging activity of a sample. The selenium complexes of Nic and RF had significantly lower $\mathrm{EC}_{50}$ value compared to trolox and $\mathrm{BHT}$. Regarding the $\mathrm{EC}_{1}$ values, the lower $\mathrm{EC}_{1}$ value the higher the ferric reducing activity of the sample. In present study, the Nic and RF selenium samples had significantly higher activity and lower $\mathrm{EC}_{1}$ than trolox $(8.35 \pm 0.12 \mu \mathrm{g} / \mathrm{ml})$ and BHT $(4.61 \pm 0.35 \mu \mathrm{g} / \mathrm{ml})$. In the $\beta$-carotene linoleic acid system assay, Nic and $\mathrm{RF}$ complexes also possessed better antioxidant activity than trolox $(54.31 \pm 2.51 \%)$ and BHT $(90.20 \pm 1.81 \%)$. The tested complexes $\left[\mathrm{Se}(\mathrm{Nic})_{4}\right] \cdot \mathrm{H}_{2} \mathrm{O}$ and $\left[\mathrm{Se}(\mathrm{RF})_{2}\right]$ showed significant higher radical scavenging activity compared to butylated hydroxyanisole (BHA) (positive control), as shown in Table V. The efficiency of an antioxidant component to reduce DPPH essentially depends on its hydrogen donating ability, which is directly related to the chemical composition of each compound. In the $\beta$ carotene linoleic acid system assay, selenium complexes have ability to block the chain reaction of lipid peroxidation mainly by scavenging the intermediate lipid peroxyl radicals which are generated [29].

TABLE V

Antioxidants activities of the BHA as positive control, selenium complexes, BHT and trolox samples.

\begin{tabular}{c|c|c|c}
\hline \hline Sample & $\mathrm{EC}_{50}[\mathrm{\mu g} / \mathrm{ml}]$ & $\mathrm{EC}_{1}[\mathrm{\mu g} / \mathrm{ml}]$ & $\mathrm{AA}[\%]$ \\
\hline $\mathrm{BHA}($ Ve control) & $1.91 \pm 0.09^{a}$ & $1.01 \pm 0.15^{a}$ & $16.26 \pm 2.31^{a}$ \\
$\mathrm{Nic}$ & $7.83 \pm 1.13^{b}$ & $3.43 \pm 0.17^{b}$ & $24.11 \pm 0.81^{b}$ \\
$\mathrm{RF}$ & $3.88 \pm 1.02^{c, e}$ & $3.38 \pm 0.61^{e}$ & $39.44 \pm 2.72^{e}$ \\
{$\left[\mathrm{Se}(\mathrm{Nic})_{4}\right] \cdot \mathrm{H}_{2} \mathrm{O}$} & $8.11 \pm 0.09^{b}$ & $2.91 \pm 0.25^{b}$ & $25.73 \pm 1.91^{b}$ \\
{$\left[\mathrm{Se}(\mathrm{RF})_{2}\right]$} & $-4.11 \pm 0.17^{c, e}$ & $3.91 \pm 0.23^{e}$ & $41.73 \pm 3.01^{e}$ \\
$\mathrm{BHT}$ & $21.51 \pm 1.61^{f}$ & $-4.61 \pm 0.35^{b, c}$ & $90.20 \pm 1.81^{f}$ \\
trolox & $6.75 \pm 0.22^{c, g}$ & $8.35 \pm 0.12^{f}$ & $54.31 \pm 2.51^{g}$
\end{tabular}

$a, b, c, d$ data bearing different superscript letters in the same raw were significantly different $(P<0.05)$. Each value is presented as means \pm standard deviation $(n=3)$.

\section{Conclusion}

This paper discussed the preparation and characterization of two new selenium(IV) complexes with nicotinamide and riboflavin vitamins. This research aimed to some items as addressing some of the vitamin drugs containing selenium as one of the important elements to reduce the free radicals, preparation of a selenium compounds in the nanometric form which gave a great impor- 
tance in increase of the efficiency of absorption of human cells to selenium while minimizing the amount of active ingredient (i.e., higher absorption and less amount), and reduce the side effects of chemical additives. This paper gives a new idea to the pharmaceutical companies through the preparation of selenium and its compounds in the nanometric form which facilitates human cells to absorbed quickly and efficiently rather than large dose, which gives high efficiency of the vital force to increase the body immune system. Screening of antioxidant activities of selenium(IV) complexes in vitro were investigated. The antioxidant activity was studied by three methods (DPPH assay; $\beta$-carotene/linoleic acid a bleaching assay and ferric reducing power assay. The studied Se(IV) complexes have a significant higher antioxidant activity compared to synthetic antioxidants like trolox and BHT.

\section{References}

[1] J.D. Odom, W.H. Dawson, P.D. Ellis, J. Am. Chem. Soc. 101, 5815 (1979).

[2] H. Robberecht, H. Deelstra, Talanta 31, 49 (1984).

[3] R.W. Andrews, D.C. Johnson, Anal. Chem. 47, 259 (1975).

[4] M.E. El-Boshy, E.F. Risha, F.M. Abdelhamid, M.S. Mubarak, T.B. Hadda, J. Trace Element Med. Biol. 29, 104 (2015).

[5] J. Pieczynska, H. Grajeta, J. Trace Element Med. Biol. 29, 31 (2015).

[6] M. Vinceti, P. Grill, C. Malagoli, T. Filippini, S. Storani, M. Malavolti, B. Michalke, J. Trace Elem. Med. Biol. 31, 1 (2015).

[7] B. Corvilain, B. Contempre, A.O. Longombe, P. Goyens, C. Gervy-Decoster, F. Lamy, J.B. Vanderpas, J.E. Dumont, Am. J. Clin. Nutr. 57, $244 \mathrm{~S}$ (1993).

[8] P. Drevensek, T. Zupancic, B. Pihlar, R. Jerala, U. Kolitsch, A. Plaper, I. Turel, J. Inorg. Biochem. 99, $432(2005)$.

[9] J.H. He, D.R. Xiao, H.Y. Chen, S.W. Yan, D.Z. Sun, X. Wang, J. Yang, R. Yuan, E.B. Wang, Inorg. Chim. Acta 385, 170 (2012).

[10] L. Kathawate, S. Sproules, O. Pawar, G. Markad, S. Haram, V. Puranik, S. Salunke-Gawali, J. Mol. Str. 1048, 223 (2013).

[11] Metallotherapeutic Drugs and Metal-Based Diagnostic Agents, the Use of Metals in Medicine, Eds. M. Gielen, E.R.T. Tiekink, Wiley, Chichester 2005.

[12] M.P. López-Gresa, R. Ortiz, L. Perelló, J. Latorre, M. Liu-González, S. Garcia-Granda, M. Pérez-Priede, E. Cantón, J. Inorg. Biochem. 92, 65 (2002).

[13] D.R. Xiao, E.B. Wang, H.Y. An, Y.G. Li, L. Xu, Cryst. Growth Des. 7, 506 (2007).

[14] D.R. Xiao, J.H. He, D.Z. Sun, H.Y. Chen, S.W. Yan, X. Wang, J. Yang, R. Yuan, E.B. Wang, Eur. J. Inorg. Chem. 11, 1783 (2012).

[15] N.M. Niren, Pharmacologic doses of nicotinamide in the treatment of inflammatory skin conditions: a review, Cutis 77 (1 Suppl): 11-6 (2006).

[16] Wikipedia, Nicotinamide.
[17] C.R. Bondy, P.A. Gale, S.J. Loeb, Chem. Commun. 8, 729 (2001).

[18] V.A. Sharnin, S.V. Dushina, M.A. Zevakin, A.S. Gushchina, K.V. Grazhdan, Inorg. Chim. Acta 362, 437 (2009).

[19] R.L. Lieberman, A. Bino, N. Mirsky, D.A. Summers, R.C. Thompson, Inorg. Chim. Acta 297, 1 (2000).

[20] B. Kozlevcar, I. Leban, I. Turel, P. Segedin, M. Petric, F. Pohleven, A.J.P. White, D.J. Williams, J. Sieler, Polyhedron 18, 755 (1999).

[21] M. Melnik, J. Mrozinski, C.E. Holloway, J. Coord. Chem. 29, 209 (1993).

[22] I. Uçar, A. Bulut, A. Karadă̆, C. Kazak, J. Mol. Struct. 837, 38 (2007).

[23] E. Şahin, S. İde, A. Ataç, S.. Yurdakul, J. Mol. Struct. 616, 253 (2002).

[24] A. Atac, S. Yurdakul, S. Berber, Spectrochim. Acta A 81, 684 (2011).

[25] S. Swavey, E.S. Gould, Inorg. Chem. 39, 352 (2000).

[26] C.N. Malele, J. Ray, W.E. Jones Jr, Polyhedron 29, 749 (2009).

[27] A.N. Singh, E. Gelerinter, E.S. Gould, Inorg. Chem. 21, 1232 (1982).

[28] O.P. Sharma, T.K. Bhat, Food Chem. 113, 1202 (2009).

[29] H. Miraliakbari, F. Shahidi, Food Chem. 111, 421 (2008).

[30] G. Ozkan, O. Sagdic, S. Gokturk, O. Unal, S. Albayrak, Food Sci. Technol. 43, 186 (2010).

[31] A.W. Coats, J.P. Redfern, Nature 201, 68 (1964).

[32] W.J. Geary, Coord. Chem. Rev. 7, 81 (1971).

[33] K. Nakamoto, Infrared and Raman Spectra of Inorganic and Coordination compounds, 3rd ed., Wiley Interscience, New York 1978.

[34] H.L. Singh, A.K. Vershney, Bioinorg. Chem. Appl. 2006, 1 (2006).

[35] O.F. Ozturk, M. Sekerci, E. Ozdemir, Russ. J. Coord. Chem. 31, 687 (2005).

[36] O.F. Ozturk, M. Sekerci, E. Ozdemir, Russ. J. Gen. Chem. 76, 36 (2006).

[37] A. Atac, S. Yurdakul, S. Berber, Spectrochim. Acta A 81, 684 (2011).

[38] J.R. Allan, N.D. Baird, A.L. Kassyk, J. Therm. Anal. 16, 79 (1979).

[39] A.H. Beckett, J.B. Stenlake, Pharmaceutical Chemistry Quantitative Analysis, Athlone Press, London 1962, p. 301.

[40] P. Scherrer, Göttinger Nachrichten Gesell. 2, 98 (1918) (in German).

[41] M.M. Omar, J. Therm. Anal. Calc. 96, 607 (2009).

[42] A. Rotaru, M. Goşa, P. Rotaru, J. Therm. Anal. Calc. 94, 367 (2008).

[43] R.K. Verma, L. Verma, A. Bhushan, B.P. Verma, J. Therm. Anal. Calc. 90, 725 (2007).

[44] M.S. Refat, I.M. El-Deen, Z.M. Anwer, S. El-Ghol, J. Mol. Struct. 920, 149 (2009).

[45] M.S. Refat, I.M. El-Deen, Z.M. Anwer, S. El-Ghol, J. Coord. Chem. 62, 1709 (2009). 